\title{
Filstortorias
}

\section{Apresentação do Dossiê:}

\section{Gênero e Sexualidade}

As categorias gênero e sexualidade remetem aos debates da epistemologia feminista na contemporaneidade que, a partir de Scott (1990) propõe desconstruir as narrativas generalizantes que ocultam, naturalizam e legitimam as hierarquias de poder entre os sexos. Para Scott (1990: 1), a palavra gênero em seu uso mais recente designa "uma rejeição ao determinismo biológico implícito no uso dos termos como 'sexo' ou 'diferença sexual'”. Ao propor o gênero como categoria de análise, ela contribui para evidenciar a dimensão ideológica e sexista do conhecimento e põe em debate, no campo da pesquisa histórica, os usos desestabilizadores dessa categoria. Scott traz a questão da desnaturalização das diferenças entre os sexos para o campo do político, que permite pensar e desconstruir as relações de poder polarizadas entre homens e mulheres. Butler (2003) vem questionar a distinção sexo/ gênero: "gênero não está para a cultura, assim, como sexo está para a natureza" (2003: 25). Tanto sexo como gênero são construções discursivas e culturais. Para a autora gênero é "um ponto relativo de convergência entre conjuntos específicos de relações culturais e historicamente convergentes" (2003: 29).

Ao abordar teoricamente a subversão das identidades de gênero como cambiantes, não fixas e mutáveis, a atitude política de Butler contribui para o fortalecimento das teorias quer, dos movimentos de gays, lésbicas e transgêneros.

Outra discussão, em foco no feminismo, é a articulação entre gênero e pós colonialismo. Parte-se do pressuposto que a categoria gênero só pode ser pensada a partir das fronteiras geográficas e sexuais dos colonizados nas sociedades ditas "terceiro-mundistas". Por esta perspectiva, Gloria Anzaldúa aposta na atitude política de "assumir a consciência mestiça”, como via possível para questionar a opressão sexista e a possibilidade de uma nova abordagem de gerar conhecimento. Em suas palavras: 
Comecei a pensar: Sim, sou chicana, mas isso não define quem eu sou. Sim, sou mulher, mas isso também não me define. Sim, sou lésbica, mas isso não define tudo que sou. Sim, venho da classe proletária, mas não sou mais da classe proletária. Sim, venho de uma mestiçagem, mas quais são as partes dessa mestiçagem que se tornam privilegiadas? Só a parte espanhola, não a indígena ou negra. Comecei a pensar em termos de consciência mestiça. O que acontece com gente como eu que está ali no entre-lugar de todas essas categorias diferentes? O que é que isso faz com nossos conceitos de nacionalismo, de raça, de etnia, e mesmo de gênero? Eu estava tentando articular e criar uma teoria de existência nas fronteiras. [...] Eu precisava, por conta própria, achar algum outro termo que pudesse descrever um nacionalismo mais poroso, aberto a outras categorias de identidade. ${ }^{79}$

Questionar, subverter e indagar são verbos que nos indicam os tempos de nossas ações, quer em face às nossas construções intelectuais, quer em relação às nossas práticas sociais. Perguntas que nos inquietam e nos põem em movimento. Mais do que perguntar "por quê?”, a questão que Glória Anzaldúa aponta é “ para onde?” Pergunta que desestabiliza os postulados de cânones já caducados pelas demandas do nosso agora e aponta possibilidades outras de sentir, perceber e conhecer os lugares de onde falamos.

Enunciar esses lugares de diferentes falas para se pensar gênero e sexualidade, é o que propõe esta edição n. 25 da Revista Em Tempo de Histórias, a partir dos dez (10) artigos que compõem o presente dossiê. No artigo, As representações do erótico e a construção da pornotopia nas capas de Ele Ela (1970-1977), Antônio Fontoura Júnior, a partir do conceito de pornotopia, indica os deslocamentos das representações do feminino de uma perspectiva romântica para uma leitura que reduz as mulheres a uma sexualidade erótica. Em Mulheres viris, mulheres monstruosas: Apontamentos sobre o romance Luzia-Home, Márcia Medeiros e Tânia Zimmermann privilegiam a literatura para pensar as relações de gênero e os seus desdobramentos danosos quando as marcas da virilidade se visibilizam na figura de uma mulher.

O artigo de Cássio Bruno de Araujo Rocha, intitulado Masculinidade e homoerotismo no Império português seiscentista: as aventuras sodomíticas do Padre Frutuoso Álvares, vigário do Matoim, toma por base a categoria sodomia para abordar, a partir de uma vivência performativa de masculinidade, a natureza do homoerotismo, da homossexualidade e da sodomia. Em Uma identidade em construção, Daniela Nunes a partir do conceito de cultura, numa perspectiva antropológica, traz reflexões sobre a relevância do contexto sociocultural e político na construção das identidades de gênero.

Em Diálogos e perspectivas: a presença das mulheres nas enchentes do Pantanal em Porto Murtinho, Ilsyane do Rosiv Kmitta e André Candido da Silva abordam a história de 
vida das mulheres nas enchentes do Pantanal. Privilegiam o uso das fontes orais e da categoria gênero para identificar o lugar de fala dessas mulheres e visibilizar suas experiências, seus silêncios e resistências. Em Mulheres sertanejas: vidas em narrativas, Melina Borges Rosa Cavalcante e Maria Espirito Santo Rosa Cavalcante Ribeiro propõem visibilizar as histórias de vida das mulheres sertanejas que se colocam como protagonistas e negociam a realização dos seus próprios desejos.

No artigo I ${ }^{\text {a }}$ República- Espaço para a Mulher no Ensino Técnico em Portugal, Luis Alberto Marques Alves discorre sobre o protagonismo social das mulheres portuguesas de 1910 a 1926, que aderem aos cursos técnicos especiais nas escolas indústrias, criados pelos governos republicanos de Portugal. O artigo Ruth de Souza entre raça e gênero: reflexões sobre a trajetória de uma Dama negra, (1921-1954) de Júlio Cláudio da Silva analisa os desdobramentos sociais da Lei 10.639/03, que estabelece a obrigatoriedade do curso de História e Cultura Afro Brasileira no ensino de História, através de um estudo biográfico sobre uma atriz negra.

Em Ser mulher-artista-engajada: Violeta Parra, Mercedes Sosa e Elis Regina na década de 60 Andrea Beatriz Wozniak-Giménez convida a pensar o feminismo na América Latina a partir da música engajada de Violeta Parra (1917-1967), Mercedes Sosa (1935-2009) e Elis Regina (1945-1982). Mulheres que através de suas vozes ousaram sonhar outras paisagens, outros espaços de poder para além das realidades contraditórias e excludentes do cone sul. O artigo O Papel da Mulher Intelectual na Libertação da Subalternidade de Gênero no Mundo Pós Colonial de Cleiton Ricardo das Neves e Amélia Cardoso Almeida propõe reflexões sobre as questões de gênero nas chamadas sociedades pós- coloniais, com enfoque no lugar de fala da mulher intelectual e o silêncio da mulher subalterna no mundo colonizado.

Inseridos na sessão temas livres apresentamos três artigos: A Independência do Brasil, a Construção do Conhecimento Histórico e a Formação para a Cidadania, a partir dos Livros Didáticos. Neste artigo Joyce Karla Pereira pontua a questão: até onde a formação para a cidadania pode ser mediatizada pelo conhecimento histórico? Através da análise dos conteúdos de livros didáticos de História, adotados pelas escolas da cidade de Lavras em Minas Gerais, a autora constrói sua reflexão sobre essa problemática. O artigo Entre o idealismo e a realidade: conflitos entre o Governo Vitor Buaiz e o Partido dos Trabalhadores no Espírito Santo (1995-1997) de Ueber José Oliveira permite reflexões sobre os conflitos políticos entre Governo Vitor Buaiz (1995-1997) e o Partido dos Trabalhadores (PT) nos anos de 1995 e 1997, no Espírito Santo. O filme La Vita é Bella é a base do artigo O Holocausto

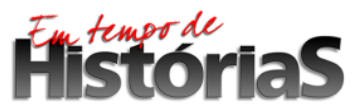


como aprendizagem de Letícia Oliveira Borges e Luiz Paulo da Silva Soares. O/a autor/a privilegiam o recurso fílmico em sala de aula para dialogar com os livros didáticos de história sobre o tema do Holocausto.

Maria do Espírito Santo Rosa Cavalcante Ribeiro Professora Titular PUC/GO

\section{Referências Bibliográficas}

COSTA, Claudia de Lima; ÁVILA, Eliana. Gloria Anzaldúa, a consciência mestiça e "o feminismo da diferença". Revista Estudos Feministas, Florianópolis, 13 (3): 320, set./dez. 2005.

BUTLHER, Judith. Problemas de Gênero: feminismo e subversão da identidade. Rio de Janeiro: Civilização Brasileira, 2003.

SCOTT, Joan. Gênero, uma categoria útil de análise histórica. Educação e Realidade, Porto Alegre, 16(2) 5-22, jul/dez. 1990. 